\title{
Robert J. Gregg July 2, 1912-November 15, 1998
}

Robert J. Gregg, Past President and founding member of the Canadian Linguistic Association, scholar, researcher, dialectologist, linguist, lexicographer, sociolinguist, teacher, department head, raconteur, family man, mentor and friend. Proud of his Irish heritage and background, Bob Gregg was born in Larne, County Antrim, Northern Ireland early in the last century of this fading millennium.

A meticulous researcher, of his many accomplishments he will perhaps best be remembered here for his work on Canadian English. Beginning with his phonological assessment of Vancouver speech in 1957, he continued with this study in conjunction with his academic colleagues, Professors Wally Avis at RMC and Harry Scargill at UVic, on the Gage series of dictionaries of Canadian English, which first appeared with the 1967 Centennial edition. During the latter part of his career, nearing retirement age, he initiated his groundbreaking Survey of Vancouver English (1978-1984). This study, which is both dialectological and sociolinguistic (Labovian) in nature, was supported by large grants from SSHRC with assistance from several other foundations. The survey, on which Margaret Murdoch, Erika Hasebe-Ludt and I were privileged to work, was one of the largest, most thorough and extensive ever undertaken in World English (a term frequently in use by Dr. Gregg). Besides creating a vast data base at UBC for future researchers, the survey spawned more than fifty articles, dissertations and other scholarly works.

A natural curiosity and love of learning marked Bob Gregg's nature; his lifelong interest in phonetics was evidently sparked in grammar school. Growing up in the locale of a Scotch-Irish dialect area attuned his hearing to the nuances of sound and meaning which were developed later through study. As a young man he took Honours in Modern Languages, both French and German, at the Queen's University in Belfast and made further study in pre-war Nazi Germany where he experienced firsthand the effects of fascism. At his other Alma Mater, the University of Edinburgh, he focussed on dialect study, particularly the provincial dialects of Ulster. His dissertation, The Scotch-Irish Dialect Boundaries in the Province of Ulster, which originally was to appear as a publication of the Irish folklore society, was published in 1985 under the same title by the Canadian Federation for the Humanities.

He and his young family moved to Canada in 1954 where he took up faculty teaching duties at UBC in the Department of French (Romance Studies) and lectured as well on French phonetics and pronunciation. While in his early career 
he taught foreign languages, at UBC he was, with several colleagues, not only instrumental in initiating ESL programmes for foreign language students but also in setting up Canada's and UBC's first language lab which was at the time state of the art. Somewhat later he transferred to the Classics Department where a Linguistics Division was created and in 1972 he was named Head of the newly formed Department of Linguistics at UBC.

Dr. Gregg will be remembered not only for his courtesy but also for the personal interest and kindnesses shown his many students, friends and colleagues. He was ever helpful in assisting with information and examples, as Ruth McConnell (1978) noted in her dedication of Our Own Voice, one of the foremost texts in Canadian English. He was proud of his students and their work and mentioned particularly often the theses of James Polson (1969) and Roberta Stevenson (1976) as well as Howard Woods' (1979) landmark dissertation, A Socio-dialectology Survey of the English Spoken in Ottawa: A Study of Sociological and Stylistic Variation in Canadian English.

When Dr. Gregg first came to UBC he told me he was asked by then-President Norman MacKenzie whether he would like to become actively involved in university affairs. For various reasons, including modesty, Dr. Gregg declined the offer. However, it was occasionally quipped later that had he accepted it is quite possible that one of UBC's many buildings might even have been named after him. If so, the establishment of a dialectology research centre would have been a fitting tribute to this man who, with Drs. Avis and Scargill, did so much to lay the early foundation for studies in Canadian English.

It was Bob Gregg's desire not only to see the completion of an atlas of Canadian English similar to those undertaken in Europe but also to see the establishment of further sociolinguistic surveys in other Canadian cities in order to achieve a cross-country comparison. It will be left now for future researchers to carry on his vision of investigating the unifying aspects of our national and regional dialect.

In his immediate family, Dr. Gregg leaves Penny, his wife of more than sixty years, a daughter, three sons, and numerous grandchildren.

Gaelan de Wolf

2706 Heron Street

Victoria, British Columbia V8R 6A2

\section{Publications}

1951. The Ulster Dialect Dictionary: Belfast Field Club's New Project. Ulster Education. September 24-25.

1953. Dialect Detective. Ireland's Saturday Night. June 1.

1957. Notes on the Pronunciation of Canadian English as Spoken in Vancouver, British Columbia. Journal of the Canadian Linguistic Association 3:20-26.

1957. Neutralisation and Fusion of Vocalic Phonemes in Canadian English as Spoken in the Vancouver Area. Journal of the Canadian Linguistic Association 3:78-83. 
1957. Introduction to the Pronunciation of French, with Phonetic Texts. Department of Romance Studies, University of British Columbia. 85 pages.

1957. Second Year University French: A Correspondence Course. (With Dr. J.G. Andison). Department of University Extension, University of British Columbia. 310 pages.

1958. Notes on the Phonology of a County Antrim Scotch-Irish Dialect (Part I: Synchronic Phonology). Orbis: Bulletin International de Documentation Linguistique VII (2): $392-406$.

1958. Review of an Anglo-Irish Dialect of North Roscommon by P.L. Henry. Orbis VII (2):582-584.

1959. Notes on the Phonology of a County Antrim Scotch-Irish Dialect (Part II: Historical Phonology). Orbis VIII (2).

1960. Review of P.L. Henry's A Linguistic Survey of Ireland: Preliminary Report (see Lochlann, vol. 1, bind V, Norsk Tidsskrift for Sprogridenskap). Orbis IX (2).

1962. Canadian Lexicography. Canadian Literature 3:68-71.

1964. Scotch-Irish Urban Speech: A Phonological Study of the Regional Standard English of Larne, Co. Antrim. In Ulster Dialects: An Introductory Symposium. Belfast.

1972. The Scotch-Irish Dialect Boundaries in Ulster. In Patterns in the Folk Speech of the British Isles, ed. M.F. Wakelin. London.

1972. Linguistic Change Observed: Three Types of Phonological Changes in the ScotchIrish Dialects. In The Proceedings of the VIIth International Congress of Phonetic Sciences. The Hague.

1973. The Linguistic Survey of British Columbia: The Kootenay Region. In Canadian Languages in Their Social Context, ed. Regna Darnell, 105-116. Edmonton: Linguistic Research.

1973. The Diphthongs [əI] and [ar] in Scottish, Scotch-Irish, and Canadian English. Canadian Journal of Linguistics 18:136-145.

1973. Dictionary of Canadian English: The Senior Dictionary. Rev. ed. Edited by W.S. Avis, R.J. Gregg, and M.H. Scargill. Toronto: Gage. 1284 pages.

1973. The Gage Canadian Dictionary. Edited by W.S. Avis, R.J. Gregg, and M.H. Scargill. Toronto: Gage. 1284 pages.

1974. The Phonology of Canadian English as Spoken in the Area of Vancouver, British Columbia. In Canadian English: Origins and Structures, ed. J.K. Chambers, 133144. Toronto: Methuen. [revision of 1957 articles above]

1975. The Distribution of Raised and Lowered Diphthongs as Reflexes of M.E.I. in two Scotch-Irish Dialects. In Phonologica 1972, ed. W.U. Dressler and F.V. Maré, 101105. Vienna.

1975. The Feature 'Dentality' as a Sociolinguistic Marker in Anglo-Irish Dialects. In VIIIth International Congress of Phonetic Sciences.

1976. Dictionary of Canadian English: The Junior Dictionary. Edited by W.S. Avis, R.J. Gregg, and M.H. Scargill. Toronto: Gage. 717 pages.

1976. Dialect Mixture in Scotch-Irish Urban Speech. Northern Ireland Speech and Language Forum. Belfast. 15 pages.

1979. Canadian English. Irish English. Collins English Dictionary. London: Collins, xxvixxvii and xxv. Both essays in 2nd ed. 1986.

1979. Do You Know the Word Saskie? Northwest Languages Newsletter 1 (3). 
1981. Canadian English. Varieties of English. Commonwealth English Series. Translated and edited by Y. Matsumura. Himeji, Japan. [This work has been published only in Japanese.]

1981. An Urban Dialect Survey of the English Spoken in Vancouver, B.C.: General Background to the Survey of Vancouver English (SVEN). In Methods/Méthodes IV: Papers from the Fourth International Conference on Methods in Dialectology, ed. H.J. Warkentyne, 41-47. University of Victoria.

1983. Local Lexical Items in the Sociodialectal Survey of Vancouver English. Canadian Journal of Linguistics 28:17-23.

1984. Final Report to the Social Sciences and Humanities Research Council of Canada on 'An Urban Dialect Survey of the English Spoken in Vancouver.' Linguistics Department, University of British Columbia.

1985. The Vancouver Survey: Grammatical Usage. In Methods V/Méthodes V: Papers from the Fifth International Conference on Methods in Dialectology, ed. H.J. Warkentyne, 179-194. University of Victoria.

1985. The Scotch-Irish Dialect Boundaries of the Province of Ulster. Ottawa: Canadian Federation for the Humanities. 286 pages.

1986. The Standard and Where We Stand Now. In Search of the Standard in Canadian English, ed. W.C. Lougheed, 157-168. Occasional Papers of the Strathy Language Unit, Queen's University.

1987. Review of Peter Trudgill, ed., Language in the British Isles. Language in Society 16:245-251.

1988. The Study of Linguistic Change in the Survey of Vancouver English. In Methods in Dialectology: [Methods VI], ed. Alan R. Thomas, 434-441. Clevedon, England: Multilingual Matters.

1989. La lexicographie de l'anglais canadien. Revue québéecoise de linguistique 18(1):151187.

1991. The Survival of Local Lexical Items as Specific Marked in Vancouver English. Orbis XXXIV (1985-1987):231-241.

1992. The Survey of Vancouver English. American Speech 67:250-267.

1993. Canadian English Lexicography. In Focus on Canada, ed. Sandra Clarke, 27-44. Amsterdam, Philadelphia: John Benjamins. 